\section{Frequency of congenital \\ craniofacial malformations in a Brazilian Reference Center}

\section{Frequência de malformações congênitas craniofaciais em um Centro de Referência Brasileiro}

Lívia Máris Ribeiro Paranaíba'

Roseli Teixeira de Miranda"

Leila Aparecida Ribeiro"

Letízia Monteiro de Barros"

Hercílio Martelli-Júnior ${ }^{\prime \prime}$, III

'Department of Oral Diagnosis, School of Dentistry, State University of Campinas. Piracicaba, São Paulo, Brazil.

"Dental School of University of Alfenas, Alfenas, Minas Gerais, Brazil.

"'Stomatology Clinic, Dental School, State University of Montes Claros, Montes Claros, Minas Gerais, Brazil.

Corresponding author: Lívia Máris Ribeiro Paranaíba. Faculdade de Odontologia da Universidade de Alfenas, Rod MG 179, Km 0 - Alfenas, Minas Gerais, Brazil - CEP 37310-000. E-mail: liviaparanaib@gmail.com

\section{Abstract}

Objective: To evaluate the frequency of craniofacial anomalies in patients treated at a Brazilian Reference Center for craniofacial deformities. Method: Retrospective epidemiological study evaluating the clinical records of 1,142 patients: 656 (57.4\%) male and 486 (42.6\%) female, between 1992 and 2008. Results: Among birth defects, nonsyndromic cleft lip and/or palate were the most frequent ones (778 cases; $68.1 \%$ ), followed by single or multiple congenital anomalies without cleft lip and/or palate ( 240 cases; $21 \%$ ), recognized syndromes or sequences (56 cases; $5 \%$ ), syndromes with orofacial cleft as a component (41 cases; $3.5 \%$ ), and orofacial clefts in association with systemic malformations (27 cases; $2.4 \%)$. Conclusions: Non-syndromic cleft lip and/or palate was the congenital defect most frequently identified, although, isolated anomalies and syndromes involving craniofacial structures were quite frequent. Furthermore, the need for studies to identify the frequency and risk factors associated with craniofacial anomalies in the Brazilian population is emphasized in order to plan comprehensive strategies and integrated actions for the development of preventive programs and treatment.

Keywords: Congenital Anomalies. Craniofacial Malformations. Cleft Lip. Cleft Palate. Information Service. Epidemiology. 


\section{Resumo}

Objetivo: Avaliar a frequência de anomalias craniofaciais em pacientes assistidos em um Centro de Referência Brasileiro para deformidades craniofaciais. Método: Estudo retrospectivo epidemiológico avaliando os prontuários clínicos de 1.142 pacientes, sendo 656 (57,4\%) do gênero masculino e $486(42,6 \%)$ do feminino, entre os anos de 1992 e 2008. Resultados: Entre os defeitos congênitos, fissura labial e/ou palatina nãosindrômica foi o mais frequente (778 casos; $68,1 \%$ ), seguido por anomalias congênitas simples ou múltiplas sem fissura labial e/ou palatina (240 casos; $21 \%$ ), síndromes ou sequências reconhecidas (56 casos; $5 \%$ ), síndromes com fissura orofacial como um componente do quadro sindrômico (41 casos; 3,5\%), e fissuras orofaciais em associação com malformações sistêmicas (27 casos; 2,4\%). Conclusões: Observou-se que o defeito congênito identificado mais frequente foi a fissura labial e/ou palatina não-sindrômica, no entanto, anomalias isoladas e síndromes envolvendo as estruturas craniofaciais foram bastante encontradas. Além disso, ressalta-se a necessidade de estudos que identifiquem a frequência e os fatores de riscos associados às anomalias craniofaciais na população brasileira, a fim de que se planejem estratégias e ações integradas para o desenvolvimento de programas preventivos e de tratamento adequado.

Palavras-chave: Anomalias Congênitas. Malformações Craniofaciais. Fissura Labial. Fissura palatina. Serviço de informação. Epidemiologia.

\section{Introduction}

Congenital anomalies (CA) are changes in structure, function and metabolism present at birth, resulting in physical or mental impairment. They may be simple or multiple, and vary in clinical importance ${ }^{1,2}$. CAs are important causes of mortality and morbidity in childhood and later in life, occurring in approximately $3-5 \%$ of newborns ${ }^{1,3}$. CAs are currently the second cause of infant mortality in Brazil, determining $11.2 \%$ of these deaths ${ }^{4,5}$. Of pregnancies with malformed fetuses more than $20 \%$ end in miscarriage; the remaining $80 \%$ will be born (alive or dead) with some kind of congenital anomaly ${ }^{1}$.

The etiology of most CA remains unknown, although there are a few well established and avoidable external risk factors ${ }^{6}$ Worldwide surveys have shown that the birth prevalence of CA varies greatly from country to country ${ }^{3,7}$. It is reported to be as low as $1.07 \%$ in Japan, and as high as $4.3 \%$ in Taiwan ${ }^{7}$. In the USA, the birth prevalence of CAs is 2-3\%, in England 2\%, in South Africa $1.49 \%$ and, in Brazil 1-3\% $\%^{3,4,8-11}$. These variations may be explained by ethnic, social, ecological, and economic influences ${ }^{3,7}$. In developing countries like Brazil and others of Latin America, childbearing-age women are exposed to potential risk factors like infectious agents and poverty diseases, environmental chemical compounds, unhealthy working conditions during pregnancy, use of medication, and maternal metabolic diseases. More than that, these risk factors interact with low schooling and low socioeconomic status in the population and scarce resources in the public health care system targeting the prevention and treatment of congenital anomalies ${ }^{4,12}$

In general, the most common CAs are nervous system anomalies (especially neural tube defects, such as spina bifida, anencephaly, and encephalocele), cleft lip and/or palate, musculoskeletal system anomalies (such as polydactyly, syndactyly and congenital clubfoot), and cardiovascular anomalies ${ }^{4,5,9,13,14}$. Moreover, in Brazil, 
urogenital anomalies are also included as the most frequent ${ }^{2}$.

Among CA, craniofacial anomalies are a large and complex group including skull and/or facial feature contour alterations. Among them are cleft lip and/or palate, craniosynostosis, holoprosencephaly, otomandibular defects, neural tube defects that affect the cephalic pole, and multisystem syndromes as Apert, Crouzon syndrome, among others ${ }^{15}$.

Undoubtedly, cleft lip and/or palate $(\mathrm{CL} / \mathrm{P})$ are the most common examples of CA and may occur in up to one in every 600 newborns, which means the birth of a patient every 2.5 minutes in the world ${ }^{15,16}$. $\mathrm{CL} / \mathrm{P}$ etiology is complex with both environmental and genetic factors playing important roles, and the intensive effort of current research has not revealed a single major risk factor for human clefting ${ }^{16}$. It has long been known that CL/P can be associated with other systemic defects, although the reported prevalence and the type of associated alterations vary among different studies, ranging from $3 \%$ to $63.4 \%{ }^{16-19}$. Also, reporting of cleft patients in the immediate postnatal period can underestimate the true frequency of associated congenital anomalies because many are still not diagnosed at birth or in the neonatal period ${ }^{20}$.

Clefting has been proposed as part of a complex malformation associated with other anomalies. The identification of specific associations with $\mathrm{CL} / \mathrm{P}$ is important for improving the definition of the classification, and the genetics, epidemiology and morphology of this malformation ${ }^{17,20}$. A combination of these approaches may be useful for public health, treatment, and preventive strategies ${ }^{17}$.

Although most patients with craniofacial anomalies have normal life expectancy, these anomalies can lead to significant abnormalities in speech, hearing, appearance, and cognition, leading to long-term adverse health events and social integration problems for individuals affected ${ }^{15}$.

In general, population-based studies on congenital malformations are rare in
Brazil and are represented by studies from hospital sources, such as the ECLAMC network (Latin American Collaborative Study on Congenital Malformations $)^{4}$. In order to better acknowledge, understand and treat the patients seen at our Service, this study aimed to evaluate the frequency of congenital craniofacial malformations in the Center for Rehabilitation of Craniofacial Anomalies of the University of Alfenas, which is a reference Center for the State of Minas Gerais.

\section{Methods}

The medical records of 1,142 patients aged 1 month to 61 years (average age, 19.1 yrs; standard deviation, 14.9) treated at the Center for Rehabilitation of Craniofacial Anomalies of the state of Minas Gerais, Brazil, between 1992 and 2008, were examined retrospectively. All incomplete medical records were excluded, such as incomplete clinical information and/or inconclusive diagnoses. This sample of patients was derived from individuals living in the state of Minas Gerais, which is mostly formed by an admixed population of Africans and Europeans (most from Portugal, Spain and Italy), with a very small percentage of indigenous Brazilians. The Brazilian population is comprised by an intense admixture of Europeans, Africans and native Indians, making the differentiation between ethnic groups difficult ${ }^{21}$. This reference service of the Brazilian Health Department comprises a multidisciplinary team of health care specialists, including plastic and dental surgeons, dentists, psychologists, pediatricians, genetic counseling professionals, nutritionists, and a speech therapist. The initial physical examination was performed by a pediatrician, followed by the multidisciplinary team.

Information obtained from medical records was analyzed according to the type of congenital craniofacial anomalies as follows (adapted from Vallino-Napoli et al., 2004 and Jaruratanasirikul et al., $2008)^{22,23}$ : (1) non-syndromic cleft lip and/ or palate (NSCL/P), a cleft occurring in the 
absence of any other structural or cognitive abnormality, (2) syndromic cleft lip and/or palate (SCL/P), an oral cleft in association with other phenotypes characterizing a syndrome, (3) recognized syndromes or sequences in the absence of cleft lip and/ or palate (RSS), (4) single or multiple congenital anomalies without cleft lip and/or palate (SMCA) - such as congenital tumors and malformations of ears, eyes, and the maxillo-mandibular complex, and (5) cleft lip and/or palate and associated malformations (CL/PAM) without definition of a syndrome.

Oral clefts were classified in 4 groups with the incisive foramen as reference ${ }^{24}$ - (1) isolated cleft lip (CL): complete or incomplete, uni or bilateral pre-foramen cleft, (2) cleft lip and palate (CLP): uni or bilateral trans-foramen cleft, (3) isolated cleft palate (CP): complete or incomplete post-foramen cleft, and (4) rare orofacial cleft (ROC). Descriptive statistical analysis was performed by using the SPSS program, version 17.0 (Chicago, EUA). The study was approved by the Ethical Research Committee of the University. There is no conflict of interest.

\section{Results}

The majority of patients affected by CA were male ( $\mathrm{n}=656,57.4 \%)$ with a male-tofemale ratio of 1.35 . The frequency of congenital craniofacial anomalies was $68.1 \%$ $(n=778)$ of NSCL/P, $21 \%(n=240)$ of SMCA,
$5 \%(\mathrm{n}=56)$ of RSS, $3.7 \%(\mathrm{n}=41)$ of SCL/P and, $2.4 \%(\mathrm{n}=27)$ of CL/PAM. Among NSCL/P patients, $204(26.2 \%)$ had CL, 382 (49.1\%) CL/P, 190 (24.4\%) CP and, 2 presented ROC (0.3\%) (Table 1). CL and CL/P were more common in males than in females (1.24:1 and 1.55:1 respectively), whereas $\mathrm{CP}$ was more frequent in females (1.26:1). When all cases were considered together, the male:female ratio was 1.21 (Table 1).

Eye anomalies represented the most common alteration in the SMCA group, corresponding to 145 out of 240 cases ( $60.4 \%$ ), followed by ear anomalies, maxillo-mandibular defects, multiple system defects, limb/ extremity anomalies, facial hemangioma, nervous system anomalies, and tongue malformations (Table 2). Patients were included as having multiple system defects when they demonstrated more than one organ/system affected by CAs. In this group, we identified 4 patients with an association of limb/extremity CA and malformations in the face and respiratory system, 3 subjects with facial and respiratory anomalies, 2 cases of limb/ extremity deformities in association with cardiac and facial malformations, 2 patients demonstrating limb/extremity and facial anomalies associated with nervous system alterations, 2 patients with an association of malformations in the face and nervous system, and 2 patients with congenital disorders in both cardiac and nervous systems. Tongue malformations were represented by ankyloglossia, fissured tongue, and aglossia.

Table 1 - Distribution of specific types of cleft according to patient sex among 778 patients with non-syndromic cleft lip/ palate (NSCL/P) seen in a Brazilian reference center, 1992-2008.

Tabela 1 - Distribuição dos tipos específicos de fissuras de acordo com o gênero entre os 778 pacientes com fissura labial e/ou palatina não-sindrômica vista em um centro de referência Brasileiro, 1992-2008.

\begin{tabular}{lcccc}
\hline & Total & Male & Female & Male:Female ratio \\
& $\mathrm{n}(\%)$ & $\mathrm{n}(\%)$ & $91(25.9)$ & 1.24 \\
\hline $\mathrm{CL}$ & $204(26.2)$ & $113(26.5)$ & $150(42.7)$ & 1.55 \\
$\mathrm{CLP}$ & $382(49.1)$ & $232(54.3)$ & $108(30.8)$ & 0.76 \\
$\mathrm{CP}$ & $190(24.4)$ & $82(19.2)$ & $2(0.6)$ & \\
ROC & $2(0.3)$ & 0 & 351 & 1.21 \\
\hline Total & 778 & 427 & \\
\hline
\end{tabular}

CL: isolated cleft lip; CLP: cleft lip and palate; CP: isolated cleft palate; ROC: rare orofacial cleft.

$C L$ : fissura labial isolada; CLP: fissura lábio palatina; CP: fissura palatina isolada; ROC: fissura orofacial rara. 
Table 2 - Frequency of single or multiple congenital malformations without cleft lip and/or palate (SMCA) identified in this study.

Tabela 2 - Frequência das malformações congênitas únicas ou múltiplas sem fissura labial e/ou palatina identificadas neste estudo.

\begin{tabular}{lc}
\hline Single or Multiple Anomalies & $\mathrm{n}(\%)$ \\
\hline Eye anomalies & $145(60.4)$ \\
Ear anomalies & $26(10.8)$ \\
Maxillo-mandibular defects & $23(9.6)$ \\
Multiple system defects & $15(6.3)$ \\
Limb/extremity anomalies & $11(4.6)$ \\
Facial hemangioma & $10(4.2)$ \\
Nervous system anomalies & $6(2.4)$ \\
Tongue malformations & $4(1.7)$ \\
\hline Total & 240 \\
\hline
\end{tabular}

A total of 56 RSS were identified. The most frequent ones were Goldenhar syndrome (6 cases, $10.7 \%$ ), Treacher Collins syndrome (5 cases, 9\%), Pierre Robin sequence (4 cases, $7.1 \%$ ), and Moebius syndrome (4 cases, $7.1 \%$ ). Other relatively common syndromes were also identified such as Crouzon syndrome, Down syndrome, and Apert syndrome. Moreover, $16(28.6 \%)$ patients had non-diagnosed syndromes (Table 3 ).

Forty-one patients had SCL/P, and the most frequent one was van der Woude syndrome (17 cases, $41.5 \%$ ) (Table 4$)$. Of

Table 3 - Frequency of syndromes and sequences without cleft lip and/or palate (RSS) identified in this study.

Tabela 3 - Frequência das síndromes e sequências sem fissura labial e/ou palatina identificadas neste estudo.

\begin{tabular}{lc}
\hline Syndromes and sequence & $\mathrm{n}(\%)$ \\
\hline Goldenhar syndrome & $6(10.7)$ \\
Treacher Collins syndrome & $5(9.0)$ \\
Pierre Robin sequence & $4(7.1)$ \\
Moebius syndrome & $4(7.1)$ \\
Crouzon syndrome & $3(5.3)$ \\
Down syndrome & $3(5.3)$ \\
Frontonasal syndrome & $3(5.3)$ \\
Apert syndrome & $2(3.6)$ \\
Sturge Weber syndrome & $2(3.6)$ \\
Hereditary ectodermal dysplasia & $2(3.6)$ \\
Orofaciodigital syndrome & $2(3.6)$ \\
West syndrome & $1(1.8)$ \\
Sotos syndrome & $1(1.8)$ \\
Rubstein-Taybi syndrome & $1(1.8)$ \\
Ellis van Creveld syndrome & $1(1.8)$ \\
Non-diagnosed syndromes & $16(28.6)$ \\
\hline Total & 56 \\
\hline
\end{tabular}


Table 4 - Distribution of clefts in the syndromes (SCL/P) observed in this study.

Tabela 4 - Distribuição das fissuras em síndromes observadas neste estudo.

\begin{tabular}{lcccc}
\hline Syndromes & Total & $\mathrm{CL}$ & $\mathrm{CLP}$ & $\mathrm{CP}$ \\
& $\mathrm{n}(\%)$ & $\mathrm{n}$ & $\mathrm{n}$ & $\mathrm{n}$ \\
\hline van der Woude syndrome & $17(41.5)$ & 2 & 13 & 2 \\
Chromosomal defects & $4(9.8)$ & 1 & 2 & 1 \\
Down syndrome & $4(9.8)$ & 0 & 2 & 2 \\
Velocardiofacial syndrome & $3(7.1)$ & 0 & 0 & 3 \\
Pierre Robin sequence & $3(7.1)$ & 0 & 0 & 3 \\
Turner syndrome & $3(7.1)$ & 0 & 0 & 3 \\
EEC & $2(4.9)$ & 0 & 2 & 0 \\
Optiz syndrome & $2(4.9)$ & 0 & 0 & 2 \\
Dysplasia Diastrophic & $1(2.4)$ & 0 & 0 & 1 \\
Orofaciodigital syndrome & $1(2.4)$ & 1 & 0 & 0 \\
Cystic Fibrosis & $1(2.4)$ & 0 & 0 & 1 \\
\hline Total & 41 & 4 & 19 & 18 \\
\hline CL: isolated cleft lip; CLP: cleft lip and palate; CP: isolated cleft palate; EEC: Ectrodactyly, ectodermal dysplasia and cleft lip/ \\
palate syndrome. \\
$\begin{array}{l}\text { CL: fissura labial isolada; CLP: fissura lábio palatina; CP: fissura palatina isolada; EEC: Ectrodatilia, displasia ectodermal e sindrome } \\
\text { de fissura labial/palatina. }\end{array}$
\end{tabular}

the remaining SCL/P group, patients were diagnosed with chromosomal defects, including 46XX, t(8;11)(p.10,p10) and 46XY, $\operatorname{inv}(18)(p .11 .1 p 11.32$, Down syndrome, velocardiofacial syndrome, Pierre Robin sequence, Turner syndrome, ectrodactyly, ectodermal dysplasia and cleft lip/palate (EEC) syndrome, Optiz syndrome, among others. Table 4 shows the syndromes and the type of cleft associated with them.
Of the 27 reported cases with CL/PAM, 9 (33.3\%) had tongue anomalies and CL/P (Table 5), and the association of $\mathrm{CP}$ with ankyloglossia was the most common (6 cases, $66.7 \%$ ). Other malformations identified were nervous system anomalies plus $\mathrm{CL} / \mathrm{P}$, extremity/limb alterations (2 patients with CL and 2 with CLP), ear and growth anomalies associated with CLP, and 2 eye malformations plus CLP (Table 5).

Table 5 - Frequency of malformations identified in this study in association with oral clefts (CL/ PAM).

Tabela 5 - Frequência das malformações identificadas neste estudo em associação com fissuras orofaciais.

\begin{tabular}{lcccc}
\hline Anomaly & Total & $\mathrm{CL}$ & $\mathrm{CL} / \mathrm{P}$ & $\mathrm{CP}$ \\
& $\mathrm{n}(\%)$ & $\mathrm{n}$ & $\mathrm{n}$ & $\mathrm{n}$ \\
\hline Tongue malformations & $9(33.3)$ & 1 & 2 & 6 \\
Nervous system & $6(22.2)$ & 0 & 4 & 2 \\
Extremity/limb alterations & $4(14.9)$ & 1 & 1 & 2 \\
Ear anomalies & $3(11.1)$ & 0 & 3 & 0 \\
Growth anomalies & $3(11.1)$ & 0 & 3 & 0 \\
Eye anomalies & $2(7.4)$ & 0 & 2 & 0 \\
\hline Total & 27 & $2(7.4 \%)$ & $15(55.6 \%)$ & $10(37 \%)$ \\
\hline CL: isolated cleft lip; CLP: cleft lip and palate; CP: isolated cleft palate. & &
\end{tabular}




\section{Discussion}

The most common congenital craniofacial anomaly identified in this study was NSCL/P with 778 cases (68.1\%). NSCL/P (OMIM 119530) is one of the most common congenital malformations observed in humans, and represents the most common craniofacial anomaly, with an incidence of approximately 1 in 600 live births worldwide $^{16,25}$. The birth incidence may vary according to ethnic factors, geographic origin, and socioeconomic level, with Asian and Native American populations having the highest rate and African ancestries having the lowest one ${ }^{16}$. In Brazil, the prevalence of NSCL/P at birth is 1.46/1000 live births ${ }^{26}$. The management of NSCL/P is complex, and families find difficulties and lack of specific guidance on how to take care of children with clefts. The most common problems of NSCL/P children are breast feeding difficulties, repeated middle ear infections, speech disarticulations, malocclusion, and staged surgical repair. Consequently, NSCL/P patients require the care of a variety of healthcare professionals (i.e., plastic surgeon, dentist, speech pathologist, otolaryngologist, geneticist, and psychologist) working as a team in the planning and delivery of treatment. There is no standard treatment strategy, timing of intervention, or surgical repair technique, but the gold standard goal is aimed at achieving intelligible speech, proper dentition, and normal facial appearance ${ }^{27,28}$.

Of the 778 NSCL/P patients, $54.9 \%$ were males with a male/female ratio of 1.21:1, which is similar to previous reports ${ }^{26,29-31}$. The most common form of cleft observed was CLP, corresponding to $49 \%$ of medical records, followed by CL (26.2\%), CP (24.4\%), and ROC $(0.3 \%)$. CP and ROC were more frequent in females, while CL and CLP were more observed in males. In general, our results were compatible with previous investigations ${ }^{16,23,26,30,32-34}$. The gender ratio has been reported in the literature to vary among the types of oral cleft $^{34}$. Males are more likely than females to have a CL with or without $\mathrm{CP}$, whereas females are at greater risk for isolated $\mathrm{CP}^{22}$. In our study, there was a difference in gender ratio for all types of oral clefts. Females were more frequent than males for isolated CP and ROC, but without statistical significance.

Oral cleft associated with other CAs or in a syndromic pattern was found in $6.1 \%$ of patients, which is within the $4.3 \%$ to $63.4 \%$ range reported by other studies ${ }^{23,35,36}$. The most frequent syndrome was van der Woude syndrome, which is also similar to previous reports ${ }^{29,37}$. Tongue malformations, nervous system alterations, and extremity/ limb anomalies were the most common disorders in the CL/PAM group, which is in disagreement with the literature. In general, malformations of the extremities and/ or skeletal system and nervous system are the most common ${ }^{33,36-38}$. CLP was the most prevalent orofacial cleft among infants with additional malformations, which is similar to other studies ${ }^{23,33,36}$.

Evidence suggests that the presence of structural and cognitive brain anomalies in $\mathrm{CL} / \mathrm{P}$ are important because the brain and the face are intimately related in normal and pathological conditions with a close relationship between the development of the face, the craniofacial skeleton, and the brain. Moreover, among patients with clefting disorders, some level of cognitive dysfunction is frequent and has been related to brain pathology (i.e., schizophrenia, bipolar diseases and mental retardation) ${ }^{39,40}$. Calzolari et al. (2006) suggested that clinical trials should be undertaken to evaluate whether neuroimaging studies in patients with apparently isolated CL/P and cognitive dysfunction should become part of clinical practice.

Among SMCA patients, the most common anomalies treated in the reference center were related to eye, ear, face, and neck anomalies (86.6\%), followed by multiple system defects $(6.3 \%)$, limb/ extremity anomalies $(4.6 \%)$ and, nervous system anomalies. In general, the most common CA reported worldwide are nervous system anomalies followed by facial anomalies (orofacial 
clefts), musculoskeletal disorders, urogenital and cardiovascular anomalies $5^{5,7,9,14}$. In part, our results are similar to these studies; although, eye, ear, face, and neck anomalies were the most common, which is probably associated with the intrinsic characteristic of the service with specialists in craniofacial deformities. In Brazil, the most frequent site and/or system of malformations are the central nervous system (e.i., spina bifida, hydrocephalus, and encephalocele), face $(\mathrm{CL} / \mathrm{P})$, osteomuscular system (e.i., gastroschisis and omphalocele), extremities/limbs (e.i., congenital clubfeet, polydactyly), and urogenital system ${ }^{2,4,9}$. Brazilian studies show some risk factors that contribute to CA in the population, such as deficient folic acid supplementation, maternal diseases (particularly diabetes mellitus), maternal age, history of abortion, maternal low schooling ${ }^{2,4,9}$.

It should be emphasized that the prevention of a significant proportion of malformations is possible, especially in the central nervous system ${ }^{4,9,41}$. The use of folic acid supplementation during the period surrounding conception significantly reduces the incidence of neural tube defects ${ }^{41}$. In Brazil, fortification of wheat and corn flour with folic acid has been mandatory since $2004^{4}$. Furthermore, the control of maternal diabetes, and possibly vitamin supplementation may also reduce the occurrence of malformations resulting from uncontrolled diabetes ${ }^{4}$.

The main syndromes and sequences identified were Goldenhar syndrome, Treacher Collins syndrome, Pierre Robin sequence, and Moebius syndrome. According to several studies, the most common syndromes observed in newborn infants with birth defects are Trisomy of the 13, 18 and $21^{3,8,14}$. However, even with a different grouping of the syndromes identified in our classification, the results were different from most studies ${ }^{3,8,23}$. Likewise, these syndromes identified in our service represent mainly disorders involving craniofacial structures that are the main focus of the center. The knowledge and the identification of all these CAs in our population allow us to lead a comprehensive strategy and integrated actions for the best possible treatment and prevention through community education, population screening, genetic counseling, and the availability of early diagnosis.

Unfortunately, it was not possible to assess the risk factors (previous abortions, maternal and/or paternal age, parity, education, family history, and outhers ${ }^{1,2,42}$ ) associated with congenital malformations identified at the Reference Center because of lack of access to medical records in hospitals. Research of possible risk factors related to congenital malformations are essential to determine which prevention and management policies should be planned and enforced. It would be interesting for the country to implement a national registry of craniofacial anomalies comprising detailed information on mothers during pregnancy, family history of affected patients, health status of newborns, re-registration, and a new assessment at a later age, among others.

\section{Conclusion}

The most common CA identified was NSCL/P; however, isolated anomalies and syndromes were also recognized and treated in this Brazilian Reference Center. This study allowed us to acknowledge the universe of patients who come to our service, providing insight to improve the planning and treatment strategy for CA patients. Furthermore, it reinforces the importance of a multidisciplinary team for the treatment of patients affected by CAs.

Acknowledgements: LMR Paranaíba is supported by Fundação Coordenação de Aperfeiçoamento de Pessoal de Nível Superior - CAPES, Brazil. Fundação de Amparo à Pesquisa do Estado de Minas Gerais - Fapemig (HMJ). 


\section{References}

1. Jones KL. Dysmorphology. In: Berman RE, Kliegman RM, Jenson HB. Nelson Textbook of Pediatrics. 17th ed. Philadelphia: WB Saunders; 2004. p. 616-23.

2. Castro MLS, Cunha CJ, Moreira PB, Fernández RR, Garcias GL, Martino-Röth MG. Frequency of multiple neonatal malformations in Pelotas, Rio Grande do Sul, Brazil, and associated socio-demographic factors. Cad Saúde Pública 2006; 22(5): 1009-15.

3. Canfield MA, Honein MA, Yuskiv N, Xing J, Mai CT, Collins JS et al. National estimates and race/ethnicspecific variation of selected birth defects in the United States, 1999-2001. Birth Defects Res A Clin Mol Teratol 2006; 76(11): 747-56.

4. Costa CMS, Gama SGN, Leal MC. Congenital malformations in Rio de Janeiro, Brazil: prevalence and associated factors. Cad Saúde Pública 2006; 22(11): 2423-31.

5. Victora CG, Barros FC. Infant mortality due to perinatal causes in Brazil: trends, regional patterns and possible interventions. Sao Paulo Med J 2001; 119: 33-42.

6. Varela MM, Nohr EA, Llopis-González A, Andersen AM, Olsen J. Socio-occupational status and congenital anomalies. Eur J Public Health 2009; 19(2): 161-7.

7. Temtamy SA, Abdel Meguid N, Mazen I, Ismail SR, Ramzy MI. A genetic epidemiological study of malformations at birth in Egypt. East Mediterr Health J 1998; 4: 252-9.

8. Dolk H. EUROCAT: 25 years of European surveillance of congenital anomalies. Arch Dis Child Fetal Neonatal Ed 2005; 90(5): F355-8.

9. Amorin MMR, Vilela PC, Santos ARVD, Lima AMV, Melo EFP, Bernardes HF, et al. Impact of congenital malformations on perinatal and neonatal mortality in an university maternity hospital in Recife. Rev Bras Saúde Matern Infant 2006; 6 (S1): S19-S25.

10. Melo LL, Carvalho MR, Wojciechowski M, Bianchim MM. Natimortalidade e malformaçöes congênitas em natimortos: estudo de frequência, fatores de risco e padräo de defeitos congênitos em uma populaçäo de Porto Alegre. Rev AMRIGS 1989; 33: 10-4.

11. Nóbrega FJ. Antropometria, patologias e malformações congênitas do recém-nascido brasileiro e estudos de associação com algumas variáveis maternas. J Pediatr 1985; 59 (S1): 6-140.

12. Schuler-Faccini L, Leite JCL, Sanserino MTV, Peres RM. Avaliação de teratógenos na população brasileira. Ciênc Saúde Coletiva 2002; 7: 66-71.

13. Pinto CO, Nascimento LSC. Prevalence study of birth defects in Vale do Paraíba, São Paulo, Brazil. Rev Paul Pediatr 2007; 25(3): 233-9.
14. Tomatir AG, Demirhan H, Sorkun HC, Köksal A, Ozerdem F, Cilengir N. Major congenital anomalies: a five-year retrospective regional study in Turkey. Genet Mol Res 2009; 13(1): 19-27.

15. Monlleó IL, Gil-da-Silva-Lopes VL. Craniofacial anomalies: description and evaluation of treatment under the Brazilian Unified Health System. Cad Saúde Pública 2006; 22(5): 913-22.

16. Mossey PA, Little J. Epidemiology of oral clefts: an international perspective. In: DF, ed. Cleft Lip and Palate: From Origin to Treatment. New York: Oxford University Press; 2002. p. 127-58.

17. Calzolari E, Pierini A, Astolfi G, Bianchi F, Neville AJ, Rivieri F. Associated anomalies in multi-malformed infants with cleft lip and palate: An epidemiologic study of nearly 6 million births in 23 EUROCAT registries. Am J Med Genet A 2007; 143(6): 528-37.

18. Fraser FC. The genetics of cleft lip and cleft palate. Am J Hum Genet 1970; 22: 336-352.

19. Shprintzen RJ, Siegel-Sadewitz VL, Amato J, Golberg RB. Anomalies associated with cleft lip, cleft palate, or both. Am J Med Genet 1985; 20: 585-95.

20. van der Veen FJ, van Hagen JM, Berkhof J, Don Griot JP. Regional underreporting of associated congenital anomalies in cleft patients in the Netherlands. Cleft Palate Craniofac J 2006; 43(6): 710-4.

21. Vieira AR, Karras JC, Orioli IM, Castilla EE, Murray JC. Genetic origins in a South American clefting population. Clin Genet 2002; 62: 458-63.

22. Vallino-Napoli LD, Riley MM, Halliday JL. An epidemiologic study of isolated cleft lip, palate, or both in Victoria, Australia from 1983 to 2000. Cleft Palate Craniofac J 2004; 41: 185-94.

23. Jaruratanasirikul S, Chichareon V, Pattanapreechawong N, Sangsupavanich P. Cleft lip and/or palate: 10 years experience at a pediatric cleft center in Southern Thailand. Cleft Palate Craniofac J 2008; 45(6): 597-602.

24. Spina V, Psillakis JM, Lapa FS, Ferreira MC. Classificação das fissuras lábiopalatinas. Rev Hosp Clin Fac Med S Paulo 1972; 27: 5-6.

25. Vieira AR. Unraveling human cleft lip and palate research. J Dent Res 2008; 87: 119-25.

26. Martelli-Júnior H, Orsi-Júnior J, Chaves MR, Barros LM, Bonan PRF, Freitas JAS. Estudo epidemiológico das fissuras labiais e palatais em Alfenas, Minas Gerais, de 1986 a 1998. Rev Fac Odontol Univ São Paulo 2006; 13(1): $31-5$.

27. Strauss RP, Broder H. Interdisciplinary team care of cleft lip and palate: social and psychosocial aspects. Clin Plast Surg 1985; 12: 543-51. 
28. Paranaíba LMR, Almeida H, Barros LM, Chaves MR, Martelli DRB, Orsi-Júnior J, et al. Surgical rehabilitation of cleft lip-palate in Minas Gerais state, Brazil. RBOtorrin 2009; 75(6): 839-43.

29. Hagberg C, Larson O, Milerad J. Incidence of cleft lip and palate and risks of additional malformations. Cleft Palate Craniofac J 1997; 35(1): 40-5.

30. Forrester MB, Merz RD. Descriptive epidemiology of oral clefts in a multiethnic population, Hawaii, 1986-2000. Cleft Palate Craniofac J 2004; 41: 622-8.

31. Martelli-Junior H, Porto LCVP, Barbosa DRB, Bonan PRF, Freitas AB, Coletta RD. Prevalence of nonsyndromic oral clefts in a reference hospital in Minas Gerais State, between 2000-2005. Braz Oral Res 2007; 21(4): 314-7.

32. Loffredo LCM, Souza JMP, Freitas FAS, Mossey PA. Oral clefts and vitamin supplementation. Cleft Palate Craniofac J 2001; 38(1): 76-83.

33. Shaw GM, Carmichael SL, Yang W, Harris JA, Lammer EJ. Congenital malformations in births with orofacial clefts among 3.6 million California births. Am J Med Genet 2004; 125: 205-6.

34. Cooper ME, Ratay JS, Marazita ML. Asian oral-facial cleft birth prevalence. Cleft Palate Craniofac J 2006; 43: 58089.

35. Wyszynski DF, Sárközi A, Czeizel AE. Oral clefts with associated anomalies: Methodological issues. Cleft Palate Craniofac J 2006; 43: 1-6.

36. Stoll C, AlembikY, Dott B, Roth MP. Associated malformations in cases with oral clefts. Cleft Palate Craniofac J 2000; 37: 41-7.
37. Milerad J, Larson O, Hagberg C, Ideberg M. Associated malformations in infants with cleft lip and palate: A prospective, population based study. J Pediatr 1997; 100(2): 180-6.

38. Sandrini FAL, Robinson WM, Paskulin G, Lima MC. Family study in orofacial clefts associated anomalies patients in the Serviço de Defeitos de Face of Pontifícia Universidade Católica of Rio Grande do Sul. Rev Cir Traumatol 2006; 6(2): 57-68.

39. Nopoulos P, Berg S, Canady J, Richman L, Van Denmark D, Andreasen NC. Structural brain abnormalities in adult males with clefts of the lip and/or palate. Genet Med 2002a; 4: 1-9.

40. Nopoulos P, Berg S, Van Denmark D, Richman L, Canady J, Andreasen NC. Cognitive dysfunction in adult males with non-syndromic clefts of the lip and/or palate. Neuropsychologia 2002b; 40: 2178-84.

41. Wolff T, Witkop CT, Miller T, Syed SB, U.S. Preventive Services Task Force. Folic acid supplementation for the prevention of neural tube defects: an update of the evidence for the U.S. Preventive Services Task Force. Ann Intern Med 2009; 150: 632-9.

42. Vrijheid M, Dolk H, Stone D, Abramshy L, Alberman E, Scott JES. Socioeconomic inequalities in risk of congenital anomaly. Arch Dis Child 2000; 82: 349-52.

Recebido em: 08/01/10

Versão final reapresentada em: 26/07/10

Aprovado em: 24/08/10 